\title{
Adam Smith's Advocacy of a Theory of Imprecise Probability in The Wealth of Nations Means that it was Impossible for him to be a Utilitarian: All Forms of Utilitarianism Necessarily Require Precise Probability as Ad- vocated by Bentham on pp.29-32,187-188 of his 1787 The Principles of Morals and Legislation
}

\author{
Michael Emmett Brady*
}

California State University, Dominguez Hills, College of Business Administration and Public Policy, Department of Operations Management 1000 East Victoria St Carson, California 90747, USA.

\begin{abstract}
Adam Smith demonstrated, repeatedly in his The Wealth of Nations in 1776 on, for example, pp.105113,pp.227-244,pp.419-423, and p.714, his commitment and adherence to his theory of imprecise and inexact probability assessment that completely conflicted with Bentham's exact, linear and additive approach based on precise probability. In chapter Four of his 1787 The Principles of Morals and Legislation, Bentham lays out an explicit and detailed account of precise probability that he restated on pp.187-188.

Bentham explains clearly in chapter four of his1787 The Principles of Morals and Legislation how his Max Utility approach is to be implemented in practice. Bentham's Max U approach requires , as a necessary condition, the use of precise probabilities(what he calls uncertainties )and precise numerical outcomes that are linear and additive so that aggregate "happiness"(material goods)can be maximized .Of course ,this is precisely what Adam Smith rejected in his virtue ethics approach .

Smith's integration of uncertainty into a decision making approach based on imprecise probability has apparently been overlooked by every single historian,economist,philosopher,sociologist,psychologist,political scientist, and decision theorist who has written on Smith in the 20th and 21st centuries. This ignorance is demonstrated in the sterile ,ongoing controversy, engaged in by numerous academic writers on Adam Smith , as to whether or not he was a utilitarian ,semi-utilitarian ,nonutilitarian, or anti- utilitarian. A knowledge of Smith's imprecise approach to probability immediately leads to the clear cut decision that he must have been either a nonutilitarian or an anti-utilitarian. There is no other possible conclusion once Smith's imprecise view of probability is acknowledged, highlighted and brought to the attention of readers of The Wealth of Nations.
\end{abstract}

Keywords: imprecise probability (A. Smith), precise probability (J. Bentham), uncertainty, Virtue ethics vs. Utilitarian Ethics, Prudence vs. Utility maximization.

\section{SECTION 1.INTRODUCTION}

Adam Smith presented a theory of imprecise probability in his The Wealth of Nations in 1776. However, academics have completely overlooked his approach to decision making for 244 years. An understanding of his theory of imprecise probability immediately leads to the conclusion that it is not possible for Smith to be a utilitarian of any sort, given his support for an imprecise approach to probability assessment. Section Two will provide an over view of Smith on probability. Section Three will cover Smith's theory of probability.

*Address correspondence to this author at California State University, Dominguez Hills, College of Business Administration and Public Policy, Department of Operations Management 1000 East Victoria St Carson, California 90747, USA; E-mail: mandmbrady@juno.com
The reader is asked to see my papers in the references that go back 10 years .Section Four will cover Hollander's 2016 paper. None of the writers debating whether Smith was a utilitarian or anti -utilitarian are aware of Smith's views on probability assessment. Section Five will conclude the paper.

Section 2 .An overview of Adam Smith's imprecise theory of probability In the Wealth of Nations in 1776,Smith gave two clearly worked out mathematical examples involving a comparison -contrast examining the concepts of precise probability(exact, definite, linear, numerical)and imprecise probability(inexact, indefinite, nonlinear,non numerical) that must incorporate uncertainty, which means there is missing or unavailable evidence that is not available to the decision maker at the time that he must make a choice between two or more different alternative options or alternatives. 
Smith's analysis is carefully presented on pp. 106-113 and pp.419-423 of the Modern Library edition of the Wealth of Nations edited by E. Cannan with the foreword by Max Lerner. It is interesting that there has not been a single academic economist, philosopher, historian, sociologist, psychologist ,political scientist ,social scientist or decision theorist in the 244 years since Smith published the Wealth of Nations in 1776 to note this fact.

The fact that Smith believed that the use of precise probability, as advocated by Jeremy Bentham, who was Smith's great intellectual opponent and adversary, was possible only under very special conditions, explains why Smith rejected utilitarianism as an ethical system and foundation for the science of economics-the requirement for precise probabilities and precise outcomes was, in general, not possible, due to the fact that there was missing or unavailable relevant information data ,knowledge or evidence that the decision maker would need to accurately estimate the consequences in the future of his present decision to act. An example of this severe misunderstanding and confusion of Smith's approach to decision making can be seen, for just one instance, in the 2016 paper by Hollander analyzed below.

Thus, discussions about whether Smith was a utilitarian ,partly a utilitarian, whatever that may mean , not a utilitarian or an anti -utilitarian, are all besides the point once it is realized that Smith completely rejected the additivity and linearity requirements of the probability calculus upon which Bentham based his utilitarianism, that all men can calculate (Bentham,1787,pp.187-188) .Smith realized that Bentham's belief in the ability to calculate future consequences was extremely limited .

Apparently, economists can't translate the English Language that Smith used to express his mathematical analysis of his approach to decision making in the Wealth of Nations. The belief that Smith did not use mathematical analysis in the Wealth of Nations can only be a conclusion reached by economists who are confused about how mathematical arguments and analysis can be presented.

This leads to the conclusion that the M. Friedman, G. Becker, and G. Stigler school of economics, that is taught at the University of Chicago, can have nothing to do at all with Adam Smith's Wealth of Nations(WN,1776) because they base all of their economic analysis on precise probability ,which is an approach that is identical to that expressed in the original work of Jeremy Bentham in chapter IV of the Principles of Morals and Legislation (1787).

Section 3. Smith on precise and imprecise probability and application in the WN on pp.106-113

Consider Smith's summary of how probability can be applied in the real world:

"The value of the risk, either from fire, or from loss by sea, or by capture, though it cannot, perhaps, be calculated very exactly, admits, however, of such a gross estimation, as renders it, in some degree, reducible to strict rule and method. The trade of insurance, therefore, may be carried on successfully by a joint-stock company, without any exclusive privilege. Neither the London Assurance, nor the Royal Exchange Assurance companies have any such privilege.”(Smith,1776, p.714)
Smith is stating in summary fashion what he had already covered in much greater detail on pp.106-113 and 419-423-it is rare that one can work with exact, definite, strict mathematical probability calculations due to the presence of uncertainty. The mathematical laws of the probability calculus cannot be applied except under some of conditions discussed by Smith on pp.106-113 of the WN.

These conditions approximate J M Keynes's requirement that the weight of the evidence, w, must equal, approach ,approximate or be close to 1 in order to use the mathematical laws of the probability calculus. Only in such cases will the probability distribution or sample space of all possible outcomes be specified and known by the decision maker in advance before he needs to choose and reach a decision. Decisions, then, based on a great deal of evidence and/or highly stable, repetitive outcomes, where the generating process is clearly understood by the decision maker, can be based on precise probabilities. However, it is usually only in some of the physical, life, and biological sciences that such precise probabilities exist.

Consider Smith's presentation of a decision problem concerning the choice to undertake a particular career choice of becoming a shoe maker or lawyer:

"Fifthly, the wages of labour in different employments vary according to the probability or improbability of success in them. The probability that any particular person shall ever be qualified for the employments to which he is educated, is very different in different occupations. In the greatest part of mechanic trades success it is almost certain; but very uncertain in the liberal professions. Put your son apprentice to a shoemaker, there is little doubt of his learning to make a pair of shoes; but send him to study the law, it is at least twenty to one if he ever makes such proficiency as will enable him to live by the business. In a perfectly fair lottery, those who draw the prizes ought to gain all that is lost by those who draw the blanks. In a profession, where twenty fail for one that succeeds, that one ought to gain all that should have been gained by the unsuccessful twenty. The counsellor at law, who, perhaps, at near forty years of age, begins to make something by his profession, ought to receive the retribution, not only of his own so tedious and expensive education, but of that of more than twenty others, who are never likely to make any thing by it. How extravagant so ever the fees of counsellors at law may sometimes appear, their real retribution is never equal to this. Compute, in any particular place, what is likely to be annually gained, and what is likely to be annually spent, by all the different workmen in any common trade, such as that of shoemakers or weavers, and you will find that the former sum will generally exceed the latter. But make the same computation with regard to all the counsellors and students of law, in all the different Inns of Court, and you will find that their annual gains bear but a very small proportion to their annual expense, even though you rate the former as high, and the latter as low, as can well be done. The lottery of the law, therefore, is very far from being a perfectly fair lottery; and that as well as many other liberal and honourable professions, is, in point of pecuniary gain, evidently under-recompensed.

Those professions keep their level, however, with other occupations; and, notwithstanding these discouragements, all 
the most generous and liberal spirits are eager to crowd into them. Two different causes contribute to recommend them. First, the desire of the reputation which attends upon superior excellence in any of them; and, secondly, the natural confidence which every man has, more or less, not only in his own abilities, but in his own good fortune. "(Smith, 1776, pp. 106-107; boldface added)" Smith has presented two very different types of decision theoretic problems in this example. The first problem deals with assessing the probability of successfully mastering the shoemaker profession. This problem is a problem of risk, where there is a great amount of solid evidence to support the decision choice because there is practically no ambiguity, vagueness or uncertainty about the expected outcome. It is similar to the first Daniel Ellsberg urn problem in Ellsberg's two urn problem. Ellsberg presented a two urn problem in 1961. The first urn had a total of 100 balls, 50 red balls and 50 black balls, while the second urn also had a total of 100 red and black balls, but in unknown proportions .The probability of successfully mastering the law -liberal arts profession problem is ,on the other hand, a problem of ambiguous probabilities involving uncertainty, similar to the second Ellsberg urn problem .

Smith rejected the Benthamite Utilitarian approach that decision makers could calculate the odds of their different choices precisely. They can't . The economics profession has gone astray since 1790 because they seriously underestimated the true genius of Adam Smith and chose to follow Bentham's highly dubious claim that decision makers can calculate the odds of all different outcomes precisely and then choose the best(optimal) one. It is not possible to apply the probability calculus if inequality constraints are present, as they are in the law-liberal arts profession problem, but not in the shoemaker profession problem.

Finally, the problem of overconfidence in the ambiguous, uncertain probabilities of successfully mastering the law profession foreshadows Ellsberg's use of the Wald optimism-pessimism index or Keynes's "animal spirits", which measured the optimism-pessimism of the decision maker and incorporated a role for it in the decision making process that is impossible to achieve in the application of precise probability, where the probabilities must always sum to exactly one.

The conclusion should be very clear here. Smith, for the very first time in history, is presenting an applied decision theoretic approach that places him heads and shoulders above any of his contemporaries. Bentham, for just one example, can only be regarded as being completely ignorant of the basic issues involved when compared to Smith concerning the reliability and accuracy of probability assessments.

Adam Smith gave a very clear, precise, and concise definition of the term uncertainty in the Wealth of Nations that has been overlooked:

" That of the Yorkshire cloth, which is made altogether of English wool, is said, indeed, during the course of the present century, to have fallen a good deal in proportion to its quality.

Quality, however, is so very disputable a matter, that I look upon all information of this kind as somewhat uncertain. "(Underline-boldface added by author ;Smith,1776, p.244)"
Smith had also stated that uncertainty comes in degrees:

"The certainty of what each individual ought to pay is, in taxation, a matter of so great importance, that a very considerable degree of inequality, it appears, I believe, from the experience of all nations, is not near so great an evil as a very small degree of uncertainty."(Smith, 1776, p.778; boldface-underline added)".

We can summarize Smith's contribution so far. Uncertainty is epistemological. It is different from the mathematical concept of risk associated with the probability calculus. A decision maker must use inexact, interval valued probabilities in the real world. The mathematical theory of probability is limited in its application to decisions where the decision maker has a great deal of relevant evidence, which is stable and invariant over time as in the shoemaker problem. Finally, Smith realized that in many cases the relevant evidence underlying and supporting the probability assessment was vague, unclear and conflicting. Exact or determinate probability estimates were not possible. However, inexact or indeterminate estimates of probabilities were possible.

Smith presented a second example of his approach to imprecise probability in Part IV of the WN:

"Thus, upon equal, or nearly equal profits, every wholesale merchant naturally prefers the home trade to the foreign trade of consumption, and the foreign trade of consumption to the carrying trade.

In the home trade, his capital is never so long out of his sight as it frequently is in the foreign trade of consumption. He can know better the character and situation of the persons whom he trusts; and if he should happen to be deceived, he knows better the laws of the country from which he must seek redress."

The uneasiness, however, which he feels at being separated so far from his capital, generally determines him to bring part both of the Koningsberg goods which he destines for the market of Lisbon, and of the Lisbon goods which he destines for that of Koningsberg, to Amsterdam; and though this necessarily subjects him to a double charge of loading and unloading as well as to the payment of some duties and customs, yet, for the sake of having some part of his capital always under his own view and command, he willingly submits to this extraordinary charge; and it is in this manner that every country which has any considerable share of the carrying trade, becomes always the emporium, or general market, for the goods of all the different countries whose trade it carries on. The merchant, in order to save a merchant, in the same manner, who is engaged in the foreign trade of consumption, when he collects goods for foreign markets, will always be glad, upon equal or nearly equal profits, to sell as great a part of them at home as he can. He saves himself the risk and trouble of exportation, when, so far as he can, he thus converts his foreign trade of consumption into a home trade.

He generally, indeed, neither intends to promote the public interest, nor knows how much he is promoting it. By preferring the support of domestic to that of foreign industry, he intends only his own security; and by directing that industry in such a manner as its produce may be of the greatest value, he intends only his own gain; and he is in this, as in many 
other cases, led by an invisible hand to promote an end which was no part of his intention.' "(Smith, 1776, pp. 421-423; boldface added)" Smith's position, that "He can know better the character and situation of the persons whom he trusts; and if he should happen to be deceived, he knows better the laws of the country from which he must seek redress." is that the businessman has far more reliable information and knowledge about the domestic trade than about the foreign trade. This is identical to Keynes's discussion and application of the weight of the evidence, w, in chapter 26 of the TP in his conventional coefficient of risk and weight,.Any discussion of weight automatically brings in nonlinearities and non additivity into formal discussions of decision theory.

Smith's analysis of decision making under uncertainty/ambiguity, as opposed to risk, is summed up in his use of the term, "Invisible Hand", on p.423 of the WN. Smith, as correctly pointed out by Gavin Kennedy (see references), used the "Invisible Hand" term as a metaphor to help readers who could not grasp the concept of decision making under uncertainty/ambiguity, where differences in the completeness of the knowledge base are extremely important ,as opposed to risk ,to come to some type of understanding of his analysis. Smith used the term here because he knew that it was practically certain that none of his readers would be able to grasp the uncertainty versus risk concept. The problem facing the decision maker on pp.419- 423 of the WN is whether to invest in the relatively certain domestic trade, which had a very high weight of evidence a la Keynes to support the point probability estimates, or to invest in the foreign trade, which had a very low weight of evidence, a la Keynes, supporting it and was highly uncertain. The probability estimates would have to be intervals in the case of the foreign trade option. The decision maker would have to concentrate on the lower bound of the interval.

This two option domestic trade-foreign trade problem is very similar to the shoemaker-lawyer problem, which is also an Ellsberg Paradox type problem very similar to Ellsberg's first problem of two urns, one with 50 red and 50 black balls and the other with a total of 100 red and black balls, but with no knowledge of the number of red and black balls. The first urn is the risky urn that around $75 \%$ of decision makers in various test situations over the last 55 years prefer to draw from while the second urn is the ambiguous or uncertain (lack of weight urn according to Keynes from chapters 6 and 26 of the TP) urn that around $20 \%$ of decision makers prefer to draw from. $5 \%$ are indifferent. This' $5 \%$ are indifferent ' figure is the correct answer according to SEU theory because the amount and quality of the evidence should play no role in the elicitation of subjective probabilities, according to Ramsey, de Finetti, Savage, and Milton Friedman.

Smith realized that the majority of business decision makers would prefer the domestic trade, as opposed to the foreign trade, because of the far greater evidentiary support available upon which to assess probabilities in the domestic trade Some decision makers prefer ambiguity and uncertainty .These decision makers would choose the foreign trade, which, as Smith pointed out, would require the use of indeterminate probabilities:
"The value of the risk, either from fire, or from loss by sea, or by capture, though it cannot, perhaps, be calculated very exactly, admits, however, of such a gross estimation, as renders it, in some degree, reducible to strict rule and method. The trade of insurance, therefore, may be carried on successfully by a joint-stock company, without any exclusive privilege. Neither the London Assurance, nor the Royal Exchange Assurance companies have any such privilege.'(Smith, 1776, p.714, author's underscore).

Of course, this indeterminate risk would not have to be dealt with at all by decision makers choosing the home trade. Note that Smith's risk concept in the above quote refers to the risk of operating in an uncertain environment or decision atmosphere and has nothing to do with the concept of risk as used by Classical, Neoclassical, and modern economists.

Smith's metaphorical use of the term, "Invisible Hand", allows a reader of the WN, who would have no understanding of Smith's very advanced decision theory, to feel that he /she had understood the nature of the conclusion Smith had reached, if not the technical nature of the analysis presented by Smith, which is 150 years ahead of his time.I note that this has been pointed out repeatedly by Kennedy since at least 2005, but ignored by academic 'Adam Smith' scholars.

Section 4.The Arguments for and against whether Smith was or was not a utilitarian both ignore Smith's imprecise theory of probability Hollander's conclusion is contained in his abstract:

"Does The Theory of Moral Sentiments reveal Adam Smith to be an "ethical utilitarian"? I approach the question by elucidating David Hume's qualifications to his own utility doctrine and the qualifications by Smith to his critique of that doctrine. I demonstrate Smith's acceptance of "happiness" as maximand, reject a narrow interpretation of the happiness entity frequently attributed to Jeremy Bentham, and confirm the role Bentham, no less than Smith and Hume, accords motivation in ethical evaluation. I conclude that the agreement amongst the three is such that to deny Smith the designation "ethical utilitarian" implies similar treatment of Hume and Bentham."(Hollander, 2016, p.557; boldface added)".

Hollander challenges the anti or non -utilitarian characterization of Smith made by Bonar, Macfie , Evensky, Haakonssen , Hanley, McCloskey, Montes, Raphael, and Witztum \& Young(see references) , as defective, based on a claim by Hollander of "Smith's acceptance of "happiness" as maximand."This conclusion is mathematically and statistically impossible if the probabilities and utilities are not linear and additive. Given Smith's rejection of the application to decision making of the linear and additive theory of precise probability accepted and advocated by Bentham in 1787(pp.29-32;pp.188-189), required by Bentham so as to operationalize his theory of utilitarianism, the goal of Bentham's utilitarianism is completely rejected, which explains why Bentham is never cited by Smith in any edition of The Theory of Moral Sentiments or The Wealth of Nations.The precise approach to probability was generally rejected by Smith, whose approach was the use of imprecise probability (nonlinear and non additive). Of course, Bonar, Macfie, Evensky, Haakonssen, Hanley, McCloskey, Montes, Rapha- 
el, and Witztum \& Young (see references ) also do not recognize the impossibility of Hollander's assessment of Smith as a utilitarian because they also were ignorant of the very severe differences over the applicability of probability by decision makers that exists between Bentham and Smith. Bentham's 'calculations' are simply an assertion on Bentham's part that Smith showed simply can't be made in the great majority of decisions. Bentham's additivity claim is rejected by Smith in toto. Without additivity, there is no maximand.

In conclusion, Smith always rejected both utilitarian and Benthamite Utilitarian approaches in The Theory of Moral Sentiments and the Wealth of Nations, based on his virtue ethics view that consequences can't be the only criteria used in ethics or morality.

The current debate among Adam Smith scholars,pro and con , about whether or not Adam Smith was or was not a utilitarian, ignores the fact that Smith's acceptance that probability assessments were imprecise means that they are not additive. This means that Bentham's chapter 4 views on the additivity of Max U approaches is rejected by Smith. S.Hollander's Maximand does not exist for Smith.

\section{SECTION 5.CONCLUSION}

Hollander connects his view of Smith as a utilitarian to others who share his position, such as Rawls, Campbell, Schneewind, Alevy and Rosen(see references). They are also wrong, given that Smith's views on imprecise probability directly contradict Bentham's views on precise probability and additivity.Smith rejects Hollander's Maximand goal.

It is unclear as to why it is the case that no academic economist, philosopher, historian, sociologist, psychologist or social scientist grasped Smith's view that exact measurement was not generally possible in economics, as opposed to Bentham's view that exact calculation was the norm in economic decision making.

Smith's position on probability makes it impossible for him to be characterized as a utilitarian.

\section{CONFLICT OF INTEREST STATEMENT}

The authors declare that they have no conflict of interest.

\section{REFERENCES}

Alvey, James E. 2003. Adam Smith: Optimist or Pessimist? Aldershot: Ashgate.

Brady, Michael Emmett, Adam Smith as an Example of Samuelson's 1952 point that Mathematics can be written out in the English Language: On Smith's Anti-Utilitarianism based on the differences between precise and imprecise probability presented in 1776 in the Wealth of Nations (November 2, 2020). Available at SSRN: https://ssrn.com/abstract=).

Brady, Michael Emmett, On Adam Smith's Major, Original Contributions to Economic Theory and Decision Making (June 7, 2014). Scholedge International Journal of Business Policy \& Governance, Vol. 03, Issue 03 (2016) pg. 39-50, Available at SSRN: https://ssrn.com/abstract $=2447270$ http://dx.doi.org/10.2139/ssrn.2447270.

Brady, Michael Emmett, A Comparison-Contrast of Adam Smith, JM Keynes and Jeremy Bentham on Probability, Risk, Uncertainty, Optimism-Pessimism and Decision Making with Applications
Concerning Banking, Insurance and Speculation (December 18, 2010). International Journal of Applied Economics and Econometrics,Volume 19, No.4,October -December 2011,pp. 86-111., Available at SSRN: https://ssrn.com/abstract $=1728225$ or http://dx.doi.org/10.2139/ssrn.1728225

Brady, Michael Emmett, Adam Smith's Theory of Probability and the Roles of Risk and Uncertainty in Economic Decision Making (June 30, 2013). International Journal of Applied Economics and Econometrics, Volume 23, No.1 (Jan.-Mar.), 2015, Available at SSRN: https://ssrn.com/abstract=2287339 http://dx.doi.org/10.2139/ssrn.2287339.

Brady, Michael Emmett, Adam Smith Was Consistent in Both the Theory of Moral Sentiments and the Wealth of Nations on the Role of the Concept of Self Interest: Das Utilitarian Economist View Is the Problem (April 3, 2018). Available at SSRN: https://ssrn.com/abstract=3156013 http://dx.doi.org/10.2139/ssrn.3156013.

Brady, Michael Emmett, From Adam Smith to John Maynard Keynes and Back to Adam Smith: The Circle Closes. The Old Economic Thinking of Smith and Keynes Combined is Still Superior to Any 'New Economic Thinking' (May 30, 2014). Available at SSRN: https://ssrn.com/abstract=2444038 http://dx.doi.org/10.2139/ssrn.2444038.

Brady, Michael Emmett, On Adam Smith's Anti-Utilitarianism in the Wealth of Nations (June 5, 2015). Available at SSRN: https://ssrn.com/abstract=2615211 http://dx.doi.org/10.2139/ssrn.2615211.

Brady, Michael Emmett, Adam Smith, the Wealth of Nations, and the 'Invisible Hand': A Metaphor for Ambiguity-Uncertainty Aversion by Decision Makers (January 24, 2015). Scholedge International Journal of Management \& Development, Vol.3, No.5, (2016), Available at SSRN: https://ssrn.com/abstract $=2554949$ or http://dx.doi.org/10.2139/ssrn.2554949.

Brady, Michael Emmett, Adam Smith, Not J M Keynes or Frank Knight, Was the First Scholar to Make the Uncertainty - Risk Distinction Explicitly and Apply it Rigorously (September 5, 2015).

Brady, Michael Emmett. (2015). Adam Smith, not J M Keynes or Frank Knight, was the First Scholar to make the Uncertainty - Risk Distinction Explicitly and Apply it Rigorously . Scholedge International Journal of Management \& Development. Vol.02, Issue 09, pp.24-36., Available at SSRN: https://ssrn.com/abstract $=2656667$ or http://dx.doi.org/10.2139/ssrn.2656667.

Brown, Charlotte. 1994. From Spectator to Agent: Hume's Theory of Obligation, Hume Studies 20 (1): 19-36.

Campbell, Tom D. 1971. Adam Smith's Science of Morals. London: Allen and Unwin.

1975. Scientific Explanation and Ethical Justification in the Moral Sentiments, Essays on Adam Smith,edited by Andrew S. Skinner and T. Wilson. Oxford: Clarendon Press, 68-82.

Evensky, Jerry. 2007. Adam Smith's Moral Philosophy, Cambridge: Cambridge University Press.

Fitzgibbons, Athol. 1995. Adam Smith's System of Liberty, Wealth and Virtue. Oxford: Clarendon Press.

Haakonssen, Knud. 1981. The Science of a Legislator: The Natural Jurisprudence of David Hume and Adam Smith. Cambridge: Cambridge University Press.

Hanley, Ryan P. 2009. Adam Smith and the Character of Virtue. Cambridge: Cambridge University Press.

Hollander, Samuel. 2013. Adam Smith: market-failure pioneer and champion of "Natural Liberty," Essays on Classical and Marxian Political Economy. London and New York: Routledge, 3-41.

2015. John Stuart Mill: Political Economist. Singapore: World Scientific

Long, Douglas G. 1990. "Utility" and the "Utility Principle": Hume, Smith, Bentham, Mill, Utilitas, 2 (1):11-39.

McCloskey, Deirdre. 2009. Adam Smith, the last of the former virtue ethicists, Elgar Companion to Adam Smith, edited by J.T. Young. Cheltenham UK: Edward Elgar, 3-24.

Macfie, A.L. 1967. The Individual in Society: Papers on Adam Smith. George Allen \& Unwin

Montes, L. 2004. Adam Smith in Context: A Critical Reassessment of Some Central Components of His Thought. London: Palgrave Macmillan.

Morrow, Glenn R. 1923. The Ethical and Economic Theories of Adam Smith. New York: Longmans Green.

Muller, Jerry Z. 1993. Adam Smith: In His Time and Ours. Princeton: Princeton University Press. 
Oakeshott, Michael. 1993 (1935). The New Bentham. Jeremy Bentham: Critical Assessments I, edited by Bhikhu C. Parekh. London and New York: Routledge, 443-56.

Raphael, David D. 1972/73. Hume and Adam Smith on justice and utility, Proceedings of the Aristotelian Society, 73: 87-103.

1975. The Impartial Spectator, Essays on Adam Smith, edited by Andrew S. Skinner and T. Wilson. Oxford: Clarendon Press, 8399.

1985. Adam Smith. Oxford: Oxford University Press.

2007. The Impartial Spectator: Adam Smith's Moral Philosophy. Oxford: Clarendon Press.

Raphael, David D. and A.L. Macfie.1976. Introduction to Adam Smith (1759) 1976. The Theory of Moral Sentiments, edited by D.D. Raphael and A.L. Macfie. Oxford: Clarendon Press, 1-52.

Rawls, John. 1999 (1971). A Theory of Justice. Revised edition. Cambridge, Mass: Belknap Press of Harvard University Press.

Rosen, Fred. 2000. The Idea of Utility in Adam Smith's Theory of Moral Sentiments, History of European Ideas, 26 (2): 79-103.
2003. Classical Utilitarianism from Hume to Mill. London and New York: Routledge.

Schneewind, Jerome B. 1998. The Invention of Autonomy: A History of Modern Moral Philosophy. Cambridge:Cambridge University Press.

Sidgwick, Henry.1877. Bentham and Benthamism in Politics and Ethics, Fortnightly Review, 21 (Issue 125):627-652.

Skinner, Andrew S. 1979. Moral philosophy and Civil Society, A System of Social Science: Papers relating to Adam Smith. Oxford: Clarendon Press, 42-67.

Stephen, Leslie 1900. The English Utilitarians I. London: Duckworth.

Witztum, Amos and Young, J.T. 2013. Utilitarianism and the role of utility in Adam Smith, European Journal of the History of Economic Thought, 20 (4): 572-602

Received: Nov 26, 2020

Copyright $($ ) 2020- All Rights Reserved

This is an open-access article. 